\title{
PENGEMBANGAN LEMBAR KEGIATAN SISWA (LKS) BERBASIS LITERASI SAINS SISWA PADA MATERI REDOKS SMAN 3 LAPANDEWA
}

\author{
Fandri $^{1}$, Maysara ${ }^{2}$ dan Muh. Alim Marhadi ${ }^{3}$ \\ 1,2,3 Jurusan Pendidikan Kimia FKIP Universitas Halu Oleo, Kendari \\ Corresponding author: maysara.fkip@uho.ac.id
}

\begin{abstract}
This study aims to describe the feasibility of student worksheets to determine scientific literacy skills in terms of theoretical feasibility (content, language, presentation and graphic criteria) and suitability with scientific literacy skills and empirical feasibility (results of scientific literacy skills and student response questionnaires). This type of research uses the 4D development method which only reaches the limited trial stage. The instruments used were study sheets and validation sheets, scientific literacy test sheets, and student response questionnaires. This worksheet was tested on 25 students of SMAN 3 Lapandewa. The validation results of the scientific literacy-based worksheets in terms of content criteria obtained a percentage of $100 \%$ with the very feasible category, language obtained a percentage of $93 \%$ with the very feasible category, Presentation obtained a percentage of $93 \%$ with the very feasible category, and graphics obtained a percentage of $94 \%$ with the very feasible category. The students' scientific literacy skills increased from an average initial test result of 42, 12 with the incomplete category to 86.40 with the complete category and the student response questionnaire sheet with an average percentage of $77.80 \%$ with the feasible category.
\end{abstract}

Keywords: scientific literacy skills, study sheets and validation sheets

\section{PENDAHULUAN}

Ilmu Pengetahuan Alam

(IPA) merupakan ilmu yang berkaitan dengan cara mencari tahu tentang gejala alam secara sistematis, sehingga IPA bukan hanya pengetahuan yang berupa fakta-fakta, konsep-konsep, atau prinsip-prinsip. Tetapi juga merupakan proses penemuan berupa produk pengetahuan. IImu Pengetahuan Alam menekankan pada tiga komponen utama yaitu sebagai proses, produk, dan sikap. Tiga komponen tersebut dikenal 
juga sebagai hakikat sains. Sebagai proses, IPA dipandang sebagai kegiatan ilmiah untuk mengetahui pengetahuan tentang alam ataupun menemukan pengetahuan baru. Sebagai produk diartikan sebagai hasil proses, berupa pengetahuan yang diajarkan di sekolah atau di luar sekolah ataupun bahan bacaan untuk menguasai pengetahuan. Sedangkan sains sebagai sikap meliputi sikap ilmiah seperti tekun, terbuka, jujur, dan objektif. Sehingga sains menjadi sangat penting dalam kehidupan seharihari bahkan dapat membantu mensejahterakan kehidupan manusia (Sulistyorini, 2007).

Kimia merupakan ilmu yang termasuk rumpun IPA sehingga mempunyai karakteristik meliputi objek ilmu, cara memperoleh, serta kegunaannya. Konsep kimia yang relatif banyak harus diserap siswa dalam waktu yang terbatas menyebabkan siswa mengalami kesulitan dalam mempelajari konsep kimia. Ilmu kimia dirasa sulit karena ilmu kimia mempunyai beberapa ciri spesifik ilmu kimia antara lain, yaitu kimia lebih bersifat abstrak, mempelajari penyederhanaan dari ilmu kimia yang sebenarnya, bahan pelajaran kimia tidak hanya menyelesaikan soal-soal. Ilmu kimia adalah ilmu yang mempelajari tentang struktur, susunan, sifat, perubahan materi, serta energi yang menyertainya. Ilmu kimia juga tidak hanya mempelajari sifat zat, tetapi berusaha mencari prinsip yang mengatur sifat-sifat materi tersebut serta merumuskan materi untuk menerangkan mengapa hal itu terjadi (Purba, 2006).

Kompetensi yang diinginkan oleh Kurikulum 2013 merupakan pembelajaran bermakna yang memungkinkan siswa menerapkan konsep-konsep IPA dan berfikir tingkat tinggi (HOTS $=$ High Order Thinking Skills) yang meliputi sikap, proses, produk dan aplikasi. Kurikulum 2013 merupakan respon terhadap perkembangan ilmu pengetahuan, teknologi, dan informasi yang berkembang pesat. Oleh karena itu, kurikulum 2013 memberikan harapan bagi terwujudnya masyarakat berliterasi sains. Hal tersebut sejalan dengan komponenkomponen yang terdapat dalam literasi ilmiah. PISA (2010), mendefinisikan literasi sains sebagai kemampuan untuk menggunakan hubungan ilmu pengetahuan dengan isu-isu ilmu pengetahuan dan aplikasinya sebagai masyarakat yang reflektif. 
Hal ini mengindikasikan bahwa siswa diharapkan

mampu menggunakan pengetahuan sains dan dapat menerapkannya dalam memecahkan masalah keseharian yang berkaitan dengan materi kimia. Dengan demikian proses pendidikan sains diharapkan mampu membentuk manusia yang melek sains dan memiliki kemampuan literasi sains yang tinggi serta mampu menguasai teknologi seutuhnya.

Rendahnya kemampuan literasi sains siswa Indonesia dipengaruhi oleh banyak hal, antara lain kurikulum dan sistem pendidikan, pemilihan metode dan model pembelajaran, sarana dan fasilitas, sumber belajar, bahan ajar, dan lainnya (Citra, 2015). Terdapat beberapa faktor yang mempengaruhi rendahnya literasi sains siswa. Pertama, rendahnya kemampuan literasi sains siswa disebabkan oleh kebiasaan pembelajaran IPA yang masih bersifat konvensional serta mengabaikan pentingnya kemampuan membaca dan menulis sains sebagai kompetensi yang harus dimiliki siswa. Kedua, kemampuan siswa dalam menginterpretasikan grafik/tabel yang disajikan dalam soal. Siswa terbiasa hanya mengisi tabel yang telah disediakan oleh guru, sehingga kemampuan siswa dalam menginterpretasikan grafik/tabel juga terbatas. Ketiga, siswa tidak terbiasa mengerjakan soal tes literasi sains. Faktor-faktor tersebut menunjukkan bahwa proses pembelajaran di sekolah sangat berpengaruh terhadap pencapaian literasi sains siswa. Salah satu cara perbaikannya dengan cara mengembangkan LKS berbasis literasi sains (Azizah, 2018).

Lembar Kerja Siswa (LKS) merupakan lembaran-lembaran berisi tugas yang harus dikerjakan oleh peserta didik. Lembar kerja biasanya berupa petunjuk, langkah-langkah untuk menyelesaikan suatu tugas. Tugas yang diperintahkan dalam lembar kerja harus jelas kompetensi dasar (KD) yang akan dicapai. Dalam menyiapkan LKS ini, tentunya guru harus cermat dan memiliki pengetahuan serta keterampilan yang memadai karena sebuah lembar kerja harus memenuhi paling tidak kriteria yang berkaitan dengan tercapai atau tidak tercapainya sebuah KD yang dikuasai oleh siswa (Depdiknas, 2008).

Namun, pada faktanya ada sekolah di Indonesia terutama 
pada tingkat jenjang menengah ke atas belum memahami tentang literasi sains. Terkait dengan kemampuan literasi sains peserta didik Indonesia, studi penilaian yang dilakukan oleh PISA mengungkapkan bahwa pembelajaran sains kurang berhasil meningkat kan kemampuan literasi sains peserta didik. Dalam Nasra (2017), hal tersebut dibuktikan dengan data bahwa Indonesia dari tahun 2000 sampai tahun 2009 selalu menempati penurunan peringkat (OECD, 2009). Hal itu juga didukung dengan hasil pra penelitian (Mitarlis, 2018), yang dilakukan di salah satu SMA yang ada diindonesia, yang ada di jawa timur yang menunjukkan sebanyak $55 \%$ siswa sudah memiliki aspek pengetahuan, $80 \%$ sudah memiliki aspek konteks, 45\% memiliki aspek kompetensi ,dan 55\% memiliki aspek sikap yang sesuai dengan kemampuan literasi sains.

Berdasarkan hasil observasi awal bersama dengan guru mata pelajaran kimia SMAN 3 Lapandewa yang telah menerapkan Kurikulum 2013 menunjukkan bahwa penggunaan lembar kegiatan siswa (LKS) kurang dilakukan atau diterapkan dan lebih mendominasi pembelajaran dengan tipe ceramah dan pemberian catatan sehingga tingkat pemahaman siswa terhadap materi kimia kurang dari yang diharapkan atau kurang dari rata-rata nilai KKM yang ditetapkan. Menurut Winarni (2018), bahwa LKS yang digunakan di sekolah hanya mengambil soal yang ada pada buku paket yang digunakan untuk mengajar sebagai tugas siswa pada kegiatan diakhir pembelajaran. Isi dari LKS tersebut sebatas soal-soal latihan berupa tes pilihan ganda dan essai, akibatnya peserta didik merasakan kejenuhan dan pasif. Permasalahan yang ditemui dalam proses pembelajaran tersebut membuat siswa malas untuk belajar dan kurang semangat untuk mempelajari materi yang diajarkan.

Reaksi oksidasi reduksi adalah salah satu konsep kimia yang bersifat kontekstual, artinya siswa dapat memahami makna materi yang dipelajarinya dengan mengkaitkan materi tersebut dengan konteks kehidupan mereka sehari-hari. Berdasarkan alasan tersebut maka konsep reaksi oksidasi reduksi dirasa cocok digunakan sebagai materi untuk 
melatihkan kemampuan literasi sains siswa.

Merujuk pada penelitian yang dilakukan oleh (Mitarlis, 2018) pengembangan lembar kegiatan siswa (LKS) untuk melatihkan kemampuan literasi sains siswa pada materi redoks, menunjukkan bahwa LKS layak digunakan, hal ini sesuai dengan hasil validasi dari LKS yang ditinjau dari kriteria isi mendapatkan persentase $78,51 \%$ dengan kategori layak; kriteria kebahasaan mendapatkan persentase sebesar $82,22 \%$ dengan kategori sangat layak; kriteria kegrafikan mendapatkan persentase sebesar $82,22 \%$ dengan kategori sangat layak; kriteria penyajian mendapatkan persentase sebesar $83,34 \%$ dengan kategori sangat layak; dan kriteria berdasarkan kesesuaian kemampuan literasi sains mendapatkan persentase sebesar $76,82 \%$ dengan kategori layak. Kemampuan literasi sains siswa meningkat dari rata-rata hasil tes awal sebesar 42,22 dengan kategori tidak tuntas menjadi 83,56 dengan kategori tuntas dan penelitian yang dilakukan oleh (Azizah, 2018) pengembangan lembar kegiatan siswa (LKS) berbasis literasi sains pada materi kesetimbangan kimia kelas XI, menunjukkan bahwa LKS yang dikembangkan layak digunakan sebagai bahan ajar yang diindikasikan telah terpenuhinya syarat kelayakan yaitu : (1) validitas yang terdiri dari validitas isi dan validitas konstruk memperoleh persentase masingmasing sebesar $77,5 \%$ dan 78,7 $\%$ dengan kategori valid. (2) kepraktisan memperoleh persentase sebesar 91,2\% dengan kategori sangat praktis. keefektifan yang ditinjau dari hasil postest mendapat nilai rata-rata 83,4 dengan kategori tuntas. Meskipun dalam penelitian ini terjadi kesamaan pada materi redoks dalam pengembangan LKS oleh Mitarlis (2018), namun karakteristik siswa pada sekolah yang menjadi lokasi penelitian sangat berbeda. Hal ini dimungkinkan hasil yang diperoleh dapat berbeda pula.

\section{METODE PENELITIAN}

Jenis penelitian ini mengacu pada metode pengembangan 4-D. Model pengembangan 4-D terdiri dari empat tahap yaitu tahap pendefinisian (Define), tahap pendesainan (Design), tahap pengembangan (Develop), dan tahap penyebaran (Disseminate). Pada penelitian ini hanya sampai pada tahap pengembangan dan $u j i$ 
coba terbatas. Hal ini dilakukan untuk mengetahui kelayakan LKS berbasis literasi sains.

Instrumen yang digunakan pada penelitian ini yaitu : Lembar telaah, lembar validasi, lembar pengamatan keterlaksanaan Pembelajaran, lembar Tes Kemampuan Literasi Sains, dan Lembar Angket Respon Siswa.

1. Lembar Telaah

Lembar telaah berisi indikator telaah untuk menelaah LKS berdasarkan kriteria kesesuaian dengan kelayakan isi, kebahasaan, penyajian, kegrafikan dan kesesuaian dengan komponen literasi sains. Telaah dilakukan oleh tenaga Ahli dibidangnya. Lembar telaah berfungsi sebagai indikator untuk mengetahui kekuatan dan kelemahan LKS untuk selanjutnya sebagai bahan perbaikan LKS.

2. Lembar Validasi

Lembar validasi berupa lembar penilaian terhadap kelayakan LKS berdasarkan kelayakan isi, kebahasaan, penyajian, dan kegrafikan serta kesesuaian dengan komponen literasi sains. Validasi dilakukan oleh tenaga Ahli dibidangnya, yaitu 2 orang dosen kimia. Penilaian ini menggunakan perhitungan dari skala likert seperti pada Tabel 1.
Tabel 1. Skala Likert

\begin{tabular}{|c|c|}
\hline $\begin{array}{c}\text { Penilaian } \\
\text { Sangat Tidak } \\
\text { Layak }\end{array}$ & Nilai Skala \\
\hline Tidak Layak & 2 \\
\hline Cukup Layak & 3 \\
\hline Layak & 4 \\
\hline Sangat Layak & 5 \\
\hline
\end{tabular}

Hasil dari lembar validasi digunakan untuk mengetahui kelayakan LKS yang dikembangkan dengan menggunakan interpretasi skor sebagaimana ditunjukkan pada Tabel 2 .

Tabel 2. Interpretasi

\begin{tabular}{|c|c|}
\hline $\begin{array}{c}\text { Skor } \\
\text { Persentase }\end{array}$ & Kategori \\
\hline $0 \%-20 \%$ & $\begin{array}{c}\text { Sangat tidak } \\
\text { layak }\end{array}$ \\
\hline $21 \%-40 \%$ & Tidak layak \\
\hline $41 \%-60 \%$ & Cukup \\
\hline $61 \%-80 \%$ & Layak \\
\hline $81 \%-100 \%$ & Sangat Layak \\
\hline
\end{tabular}

3. Pengamatan Keterlaksanaan Pembelajaran

Keterlaksanaan

pembelajaran dengan menggunakan LKS yang dikembangkan berisi tahapantahapan yang dilakukan oleh guru dan diisi oleh pengamat dengan skor 0 dan 1. 
Perhitungan untuk data ini menggunakan skala Guttman dengan kriteria peseprti pada Tabel 3 sebagai berikut.

Tabel 3. Skala Guttman

\begin{tabular}{|c|c|}
\hline Jawaban & Nilai/Skor \\
\hline Ya & 1 \\
\hline Tidak & 0 \\
\hline
\end{tabular}

Data yang diperoleh kemudian dihitung persentasenya menggunakan rumus berikut: Persentase $(\%)=$ jumlah skor/skor maksimal $x 100 \%$. LKS yang dikembangkan dikatakan layak apabila memperoleh persentase jawaban " $Y a$ " sebesar $\geq 61 \%$.

\section{Lembar Tes Kemampuan}

Literasi Sains

Instrumen ini berupa lembar soal tes yaitu lembar tes awal dan tes akhir. Lembar soal tes awal dan tes akhir digunakan untuk mengetahui kemampuan literasi sains setelah dilakukan uji coba pada pembelajaran dengan menggunakan LKS yang dikembangkan. Dari hasil tes awal dan tes akhir tersebut peneliti akan dapat mengetahui keterampilan literasi sains siswa. Data hasil tes awal dan tes akhir menunjukkan kemampuan literasi sains siswa yang diperoleh setelah belajar menggunakan

LKS yang

dikembangkan. Data hasil tes awal dan tes akhir yang diperoleh dianalisis dengan rumus :

Nilai $=\frac{\text { Jumlah skor yang diperoleh }}{\text { jumlah skor maksimal }} \times 100$

Pencapaian ideal untuk ketuntasan kompetensi ditetapkan minimal memenuhi nilai $\geq 62$, sesuai standar KKM untuk mata pelajaran kimia SMA Negeri 3 Lapandewa.

5. Lembar Angket Respon Siswa Lembar angket digunakan untuk mengumpulkan informasi yang diperlukan dan digunakan untuk mengetahui respon siswa terhadap LKS yang telah dikembangkan. Angket respon siswa yang diberikan kepada siswa yang mengikuti uji coba produk terbatas yaitu kepada 25 siswa kelas $X$ SMAN 3 Lapandewa disusun dalam bentuk pilihan jawaban "ya" untuk skor 1 atau "tidak" untuk skor 0. Data yang diperoleh kemudian dihitung persentasenya menggunakan rumus berikut :

Persentase $(\%)=$

$$
\frac{\text { Jumlah skor }}{\text { jumlah responden }} \times 100
$$

\section{HASIL DAN PEMBAHASAN}

Hasil penelitian pengembangan lembar kegiatan siswa (LKS) berbasis literasi sains yang dilakukan sesuai dengan 
metode 4-D sampai pada tahap uji coba terbatas diuraikan sebagai berikut :

\section{Hasil Validasi}

Validasi terhadap hasil revisi dari penelaah dilakukan oleh 2 validator, 2 dosen yang sesuai dengan bidangnya masing-masing. Hasil dari kedua validator tersebut nantinya akan menunjukkan layak atau tidaknya sebuah LKS. Hasil validasi terhadap tiga LKS yang dikembangkan ditunjukkan pada Tabel 4..

Tabel. 4. Hasil Validasi LKS

\begin{tabular}{lcccc}
\hline \multicolumn{1}{c}{ Aspek } & LKS I & LKS II & $\begin{array}{c}\text { LKS } \\
\text { III }\end{array}$ & Kategori \\
\hline Isi & $100 \%$ & $100 \%$ & $100 \%$ & Sangat Layak \\
Kebahasaan & $93 \%$ & $93 \%$ & $93 \%$ & Sangat Layak \\
Kegrafikan & $96,5 \%$ & $93 \%$ & $93 \%$ & Sangat Layak \\
Penyajian & $93 \%$ & $93 \%$ & $93 \%$ & Sangat Layak \\
\hline
\end{tabular}

Kriteria isi LKS berbasis literasi sains yang dikembangkan meliputi : 1) kesesuaian dengan $K D$, 2) kesesuaian dengan indikator, 3) kesesuaian tujuan pembelajaran dengan indikator. Hasil kriteria isi bertujuan untuk mengetahui kesesuaian isi LKS dengan kriteria yang berhubungan dengan validitas isi. Secara ratarata hasil validitas isi memperoleh persentase $100 \%$ yang memenuhi kriteria isi dengan kategori sangat layak. Hal ini menunjukkan bahwa LKS yang dikembangkan sudah sesuai dengan ketentuan. Validitas pada aspek kebahasaan bertujuan untuk mengetahui kesesuaian LKS dengan kriteria yang berhubungan dengan kelayakan kebahasaan. LKS yang dikembangkan meliputi tiga aspek, diantaranya : 1) keefektifan kalimat pada soal-soal yang disajikan, 2) penggunaan bahasa yang singkat dan jelas, 3 ) penggunaan simbol/lambang yang konsisten. Secara rata-rata hasil validitas pada aspek kebahasaan memperoleh persentase 93\% yang memenuhi kriteria kebahasaan dengan kategori sangat layak. Hal ini menunjukkan bahwa LKS yang dikembangkan sudah sesuai dengan ketentuan.

Validitas pada aspek penyajian memperoleh persentase rata-rata sebesar 93\% dengan kategori sangat layak. Aspek 
penyajian bertujuan untuk mengetahui kesesuaian LKS dengan aspek yang berhubungan dengan penyajian. Penilaian terhadap aspek penyajian pada LKS yang dikembangkan meliputi :

1) Urutan materi sistematis, 2) Penyajian yang menyenangkan atau menarik, 3) Cover menarik dan mempresentasikan isi LKS. Validitas pada aspek kegrafikan memperoleh persentase rata-rata 94\% dengan kategori sangat layak. Aspek kegrafikan yang bertujuan untuk mengetahui kesesuaian LKS yang dikembangkan dengan kriteria yang berhubungan dengan kegrafikan. Penilaian pada aspek kegrafisan meliputi : Penggunaan font dan ukuran teks yang digunakan memudahkan pembaca.

Validasi ini juga digunakan untuk menguji kelayakan kesesuaian dengan kemampuan literasi sains terhadap LKS yang dikembangkan. Berikut adalah hasil penilaian validator terhadap LKS yang dikembangkan, sebagaimana Tabel 5.

Tabel 5. Hasil Validasi Kriteria Kesesuaian Kemampuan Literasi Sains pada LKS

\begin{tabular}{llllc}
\hline \multirow{2}{*}{ No. } & Aspek Literasi & \multicolumn{3}{c}{ Penilaian } \\
\cline { 3 - 5 } & & LKS I & LKS II & LKS III \\
\hline 1. & Literasi Nominal & $75 \%$ & $75 \%$ & $75 \%$ \\
2. & Literasi Fungsional & $75 \%$ & $75 \%$ & $75 \%$ \\
3. $\quad$ Literasi Konseptual & $75 \%$ & $75 \%$ & $75 \%$ \\
4. $\quad$ Literasi & $75 \%$ & $75 \%$ & $75 \%$ \\
& Multidimensional & & & \\
\hline
\end{tabular}

Hasil validasi menunjukkan bahwa LKS berbasis literasi sains pada materi redoks yang dikembangkan ditinjau dari kriteria berdasarkan kesesuaian dengan kemampuan literasi sains. Literasi nominal memperoleh persentase rata-rata sebesar $75 \%$ dengan kategori layak, literasi fungsional memperoleh persentase rata-rata sebesar $75 \%$ dengan kategori layak, literasi konseptual memperoleh persentase rata-rata sebesar $75 \%$ dengan kategori layak, dan literasi multidimensional memperoleh persentase rata-rata sebesar $75 \%$ dengan kategori layak. Berdasarkan hasil penelitian 
yang diperoleh dapat dikatakan bahwa LKS berbasis literasi sains yang dikembangkan layak secara validitas teoritis.

\section{Hasil Kualitas Keterlaksanaan Pembelajaran}

Hasil aktivitas siswa

terhadap

keterlaksanaan

pembelajaran pada materi pokok reaksi redoks dilakukan dengan menggunakan lembar observasi keterlaksanaan model pembelajaran. secara singkat aktivitas siswa setiap pertemuan dapat dilihat pada Tabel 6 . sebagai berikut :

Tabel 6. Rekapitulasi Aktivitas Siswa dalam Pembelajaran

\begin{tabular}{lcc}
\hline No. & Pertemuan & $\begin{array}{c}\text { Persentase } \\
(\%)\end{array}$ \\
\hline 1. & $\begin{array}{c}\text { Pertemuan } \\
\text { Pertama }\end{array}$ & 88 \\
\hline 2. & $\begin{array}{c}\text { Pertemuan } \\
\text { kedua }\end{array}$ & 94 \\
\hline 3. & $\begin{array}{c}\text { Pertemuan } \\
\text { Ketiga }\end{array}$ & 94 \\
\hline
\end{tabular}

Berdasarkan Tabel 3. dapat diketahui bahwa setiap pertemuan persentase keterlaksanaan pembelajaran cenderung meningkat dan berada pada kategori sangat baik. Pertemuan pertama persentase sebesar $88 \%$.
Pada pertemuan ini masih terdapat beberapa siswa yang kurang mampu untuk meenyesuaikan diri dengan model pembelajaran PBL. Pertemuan kedua dan pertemuan ketiga persentase meningkat sebesar $94 \%$. Pada pertemuan ini siswa sudah mulai terbiasa menyesuaikan dengan model pembelajaran PBL.

Hasil Tes Kemampuan Literasi Sains

Data hasil tes keterampilan literasi sains ini akan menjadi nilai dari kelayakan empiris LKS yang dikembangkan. LKS yang telah di telaah dan di validasi selanjutnya dilakukan uji coba terbatas. Urutan uji coba terbatas ini yaitu siswa diberikan soal yang bernuansa literasi sains berupa soal tes awal dan tes akhir. Tes awal diberikan kepada siswa sebelum menggunakan LKS yang dikembangkan, hal ini bertujuan untuk melacak kemampuan literasi sains siswa pada materi Redoks. Setelah siswa diberikan soal tes awal, dilakukan proses pembelajaran dengan menggunakan LKS berbasis literasi sains tersebut. Setelah pembelajaran selesai, siswa kembali diberikan soal tes akhir. Soal tes akhir diberikan setelah 
siswa menggunakan LKS yang dikembangkan, hal ini bertujuan untuk mengetahui seberapa besar peningkatan hasil belajar siswa sebelum dan sesudah menggunakan LKS yang dikembangkan. Berikut Tabel data hasil tes awal dan tes akhir kemampuan literasi sains, sebagaimana ditunjukkan pada Tabel 7.

Tabel 7. Persentase Ketuntasan Hasil Belajar

\begin{tabular}{ccc}
\hline$\%$ & Tes Awal & $\begin{array}{c}\text { Tes } \\
\text { Ketuntasan }\end{array}$ \\
\hline$T T$ & $100 \%$ & $4 \%$ \\
$T$ & 0 & $96 \%$ \\
Rata-rata & 42,12 & 86,40 \\
\hline
\end{tabular}

Berdasarkan Tabel 7 diketahui bahwa hasil tes awal terhadap 25 siswa yang dilakukan sebelum uji coba, semua siswa tidak tuntas karena nilai hasil tes awal $\leq 62$ dengan nilai rata-rata 42,12 Ketidaktuntasan tersebut disebabkan karena kurangnya pengetahuan siswa dan kurang terbiasa dalam menyelesaikan soal-soal yang bernuansa literasi sains khususnya pada materi reaksi reduksi oksidasi. Siswa tidak mampu menentukan contoh aplikatif penerapan materi kimia didalam kehidupan sehari-hari. Hal ini sesuai dengan Mitarlis (2018) dalam penelitiannya di SMA NU 1 Gresik.

Hasil tes akhir terhadap 25 siswa yang diberikan setelah pembelajaran dilakukan, dapat diketahui bahwa 24 siswa dinyatakan tuntas karena mendapatkan nilai lebih $\geq 62$, sedangkan hanya satu siswa yang belum dinyatakan tuntas karena mendapatkan nilai kurang dari $\leq 62$, dengan nilai rata-rata hasil tes akhir 86,40. Ketuntasan ini menunjukkan bahwa siswa dapat menerima materi yang disajikan pada LKS sebagai informasi yang bermakna. Nilai yang telah didapatkan oleh siswa menunjukkan bahwa kegunaan dan aplikasi materi kedalam kehidupan sehari-hari memberikan motivasi intrinsik bagi siswa. Selain itu, siswa diajak untuk terlibat aktif dalam membangun pengetahuannya dari mulai mencari fenomena yang terjadi disekitarnya sehingga ditemukan konsep dari materi yang dipelajari. Hal ini sesuai dengan Azizah (2018) dalam penelitiannya di SMAN 7 Surabaya.

\section{Hasil Lembar Angket Respon Siswa}


Hasil angket respon siswa yang diisi oleh 25 siswa setelah melakukan uji coba menyatakan bahwa dengan menggunakan LKS berbasis literasi sains dapat memberikan respon positif terhadap pembelajaran kimia khususnya materi reaksi reduksi dan oksidasi.

Berdasarkan Tabel 5, lembar angket respon siswa diperoleh rata-rata hasil lembar angket respon siswa, bahwa LKS mendapatkan respon dengan persentase $77,80 \%$, sehingga dapat dinyatakan memenuhi kriteria atau dideskripsikan layak secara empiris. Hal ini menunjukkan bahwa LKS yang dikembangkan dapat digunakan dalam pembelajaran kimia, untuk kepentingan literasi sains siswa.

\section{KESIMPULAN}

Berdasarkan data penelitian yang telah dianalisis maka ditarik kesimpulan :

1. Pengembangan LKS berbasis literasi sains pada materi redoks ditinjau dari kelayakan teoritis (kriteria isi, kebahasaan, penyajian dan kegrafikan) dengan kategori sangat layak serta kesesuaian dengan kemampuan literasi sains siswa dengan kategori layak.

2. Pengembangan LKS berbasis literasi sains pada materi redoks ditinjau dari kelayakan empiris (hasil kemampuan literasi sains) meningkat dari rata-rata hasil tes awal sebesar 42,12 menjadi 86,40 serta lembar angket respon siswa dengan rata-rata persentase $77,80 \%$ dengan kategori layak.

\section{DAFTAR PUSTAKA}

Azizah, Utiya.,dkk. 2018. Pengembangan Lembar Kegiatan Siswa (LKS) Berbasis Literasi Sains Pada Materi Kesetimbangan Kimia Kelas XI. Unesa Journal Of Chemical Education. UNS.7 (3).

Citra, A. D.,Baiq. C. N.,Suryati. 2015. Pengembangan Bahan Ajar Kapra Berbasis Literasi Sains Pada Materi Laju Reaksi Untuk Kelas XI SMA / MA. Jurnal Ilmiah Pendidikan Kimia "Hydrogen". Program Studi Pendidikan Kimia, FPMIPA IKIP Mataram. 3 (1). 
Depdiknas. 2008. Panduan Pengembangan Bahan Ajar. Jakarta. Depdiknas.

Mitarlis., Riyadhin, Achmad, I. F. 2018. Pengembangan Lembar Kegiatan Siswa (LKS) Untuk Melatihkan Kemampuan Literasi Sains Siswa Pada Materi Redoks. Unesa Journal Of Chemical Education. Kimia FMIPA UNS. 1 (1).

Nasra, Edi.,Yusmaita, Eka. 2017. Perancangan Assesmen Literasi Kimia Dengan Menggunakan Model Of Educational Rekonstruction (MER) Pada Tema Air Sebagai Pelarut Universal. Jurnal Eksakta Pendidikan (JEP). UNP. 1 (2).

OECD.2009. PISA 2009 Assessment Framework Key competencies in reading, mathematics and science. [online].Tersedia:http://ww w.oecd.org/dataoecd/11/40/ 44455820.pdf [10 Januari 2020].
Purba, Micheal. 2006. Kimia Untuk SMA Kelas $X$. Jakarta : Erlangga.

PISA. 2010. Assessment Framework Key Competencies In Reading, mathematics and science. OECD.

Sulistyorini, S. 2007. Model Pembelajaran IPA Sekolah Dasar dan Penerapannya dalam KTSP. Semarang: Tiara.

Winarni, Rani. 2018. Pengembangan Lembar Kerja Siswa (LKS) Berbasis Pendekatan Saintifik Materi Termokimia Untuk Meningkatkan Keterampilan Berpikir Kritis Siswa Kelas XI $\mathrm{MIPA}_{4}$ SMA Negeri 5 Kendari. Skripsi. Kendari: Pendidikan Kimia FKIP UHO. 